\title{
Habitat Islands on the Aegean Islands (Greece): Elevational Gradient of Chasmophytic Diversity, Endemism, Phytogeographical Patterns and need for Monitoring and Conservation
}

\author{
Anna Kontopanou and Maria Panitsa * (D) \\ Department of Biology, Division of Plant Biology, Laboratory of Botany, University of Patras, \\ University Campus, GR-26504 Rio, Greece \\ * Correspondence: mpanitsa@upatras.gr
}

Received: 4 December 2019; Accepted: 16 January 2020; Published: 17 January 2020

check for updates

\begin{abstract}
The Aegean archipelago, characterized as a natural laboratory for research concerning plant species diversity and phytogeography has a complex geological and paleogeographical history that varies among its phytogeographical areas. A different combination of factors of variable intensity and duration time drives patterns of its impressive plant species richness and endemism. Cliffs, a conspicuous feature of the Aegean landscape, consist of biologically closed communities that serve as refugia for obligate chasmophytes, the majority of which are Greek or Aegean endemics, and for this reason, they are also considered as habitat islands on the Aegean islands. A synoptic analysis is presented concerning chasmophytic plant diversity focusing on endemic obligate chasmophytes. Phytogeographical patterns of obligate chasmophytes, and especially the endemic ones as well as their elevational range and distribution and zeta diversity, are analyzed and discussed in the frame of climatic change, mentioning that the most threatened endemic obligate chasmophytes are those specialized in high elevation areas, and focusing on the need for monitoring and conservation.
\end{abstract}

Keywords: obligate chasmophyte; specialist taxa; Aegean endemic; regional endemic; zeta diversity; spatial turnover

\section{Introduction}

The Mediterranean Basin constitutes the second largest hotspot at a global scale and its European part is one of the world's major centers of plant diversity [1] due to an ensemble of highly heterogeneous habitats with diverse topographies, soil types, and microclimates related to altitude, slope exposure, and precipitation [2]. At its eastern part, the Aegean archipelago, lying at the crossroads of three biogeographical regions, consists of more than 8000 islands and islets, being one of the largest archipelagos in the world [3]. It is characterized by high environmental and topographical heterogeneity, complex paleogeography, and high diversity and endemism [4], consequently, it has the potential to become a model study area globally, especially for land-bridge, continental islands [5].

The whole Aegean archipelago, characterized as a natural laboratory for biodiversity, biogeography, and evolution by many researchers, has a complex geological and paleogeographical history that varies among its phytogeographical areas, and a different combination of factors of variable intensity and duration time that drives patterns of its impressive plant species richness and endemism [6]. Most of the Aegean islands are of continental origin, except those of the South Aegean Volcanic Arc, one of the most significant geological structures of the Mediterranean [7] (and references therein). The Aegean area is one of the floristically well-mapped areas, mainly within the framework of several detailed projects [8] and many studies concerning the flora, endemism, and phytogeography in the Aegean 
region have been published [6,9] and the Atlas of the Aegean Flora [10,11] comprises all species and subspecies of native and naturalized vascular plants from at least one Aegean island area.

Cliffs, a conspicuous feature of the Aegean landscape, consist of biologically closed communities that serve as refugia from unfavorable climatic change, competition by more aggressive level-ground vegetation, and grazing [12]. Obligate chasmophytes may have persisted alongside plants characteristic of contemporary garrigues, phrygana, and maquis vegetation during the glacial maxima [13-15].

Cliffs consist of habitat islands on the Aegean islands, being discrete patches of habitats surrounded by strongly contrasting habitats [16]. Chasmophytic ecology is a secondary development for plant taxa that are 'habitat specialists' with narrow niches, that do not have the chance to colonize other habitats, but have many functional characteristics in common specific to a particular environment and for this reason, they are important in functioning of ecosystems since their loss leads to a decrease in the functional diversity of communities [12,17-20]. Niche differentiation is, according to the specialist model, supposed to be accompanied by differentiation between endemic and widespread species for biological, ecological, and life-history traits [21], and endemic species tend to exhibit traits associated with stress tolerance [22]. With regard to the question of why rare plants occur where they do in terms of plant physiological reactions, the refuge model sensu Gankin and Major [23] gives the only explanation that fits the diversity of facts-that is, plants occurring at higher or lower altitudes than normal, in wetter habitats or drier, with less calcium or more-in terms of plant competition.

Chasmophytic communities are characterized by the participation of species of high biogeographical interest as the number of endemic taxa that is particularly important, while the degree of vegetation cover is always very weak [24]. Most endemic species are chasmophytes (among others [14,25,26]). The high rate of endemism is due to periodic climate change causing the local extinction of some cliff species, but not others, followed by a very slow rate of reinvasion [12].

Cliffs, screes, rocky, and other habitats with high stress level are dominated by stress tolerators and correlate to the abundance of endemics for the whole Mediterranean area [27] as well as for the Aegean area [6] (and references therein). Snogerup [17] and Runemark [28] stated that there was a less competitive nature of the endemic Aegean flora, which grows almost exclusively in habitats where they are permitted to grow by stronger competitors.

The geographical limits of the saxatile communities are primarily determined by climate, type of substrate/rock, and their local distribution by the aspect (exposure) of the cliffs underlining that light supply, the wind, the insolation, and the differences in the minor habitats (Pavement, Sloping rock, Vertical rock, Overhanging rock, Step-crevice, and Ledge), are also highly important in determining the differentiation of chasmophyte communities [13,29-31]. Horvat et al. [32] were the first to classify the vegetation of calcareous cliffs of the thermo- and meso-Mediterranean belts of the Aegean region. Zaffran [33] studied the cliff vegetation of Crete found at altitudes spanning the sea level and ca. $1200 \mathrm{~m}$. Dimopoulos et al. [34] studied the high-rank syntaxa of the rock-cliff and scree vegetation of mainland Greece and Crete, and Bergmeier [35] focused on the vegetation of the high mountains of Crete. Bergmeier et al. [36] validated the alliances of chasmophytic vegetation within Cirsietalia chamaepeuces (Asplenietea trichomanis), - an order of the thermo- and meso-Mediterranean chasmophyte-rich vegetation of calcareous cliffs of the Aegean region. They classified Petromarulo-Centaurion argenteae as being restricted to the cliff vegetation of western Crete, Asterion cretici to the eastern Cretan cliffs, Capparo-Amaracion to the north and central Aegean vegetation of calcareous cliffs, Inulion heterolepidis to calcareous cliffs on southeast Aegean islands, and Polygonion icarici to Aegean non-calcareous cliffs of the islands of Ikaria and Samothraki. The character taxa of these five alliances are in their great majority Greek, Aegean, or Cretan endemics.

The increase of endemism with elevation has been attributed to the increased isolation of higher elevations [37]. Drivers of elevational gradients of biodiversity are climatic variables (like temperature and rainfall), spatial aspects (area size and geometric constraints), evolutionary history, and biotic processes [38]. The species richness-elevation relationships are mainly decreasing or hump-shaped, while endemism-elevation relationships are increasing and unimodal [37]. Since higher-elevation 
zones are more isolated from each other, less connected, and have a smaller extent than lower-elevation zones, they are expected to be decreasingly species rich, but contain increasingly high proportions of endemics [39]. Studies concerning the global increase of endemism with isolation on islands and continental mountains [34], elevation-driven ecological isolation on Mediterranean islands [35], and elevational gradient of vascular species richness and endemism in Crete [37] have given important insights for understanding diversity patterns along environmental gradients for continental islands. Elevational gradients of vascular plant species and endemism on Mediterranean islands such as Baleares, Croatian islands, Corsica, Sardinia, Cyprus, the Ionian islands, Crete, and Euboea have been studied by Trigas et al. [37], Steinbauer et al. [39,40], Nikolić et al. [41], Fois et al. [42], and Valli et al. [43].

Panitsa and Kontopanou [24] studied the diversity of chasmophytes in the vascular flora of Greece at a national level. Studies concerning elevational gradients of chasmophytes on Mediterranean islands, especially on Aegean islands, to our knowledge have not been studied previously. The aim of the present study was to reveal, in detail, the diversity, endemism, and phytogeographical patterns of chasmophytes of the Aegean islands, focusing on their distribution at different elevational gradients and on the spatial turnover of their diversity. A broad knowledge of chasmophytic diversity and endemism provides the opportunity for their substantial conservation on islands.

\section{Materials and Methods}

In the framework of the authors' research concerning the floristic diversity of endemic, rare, and protected plant taxa on cliffs and rocky slopes of Greece [24], a database table was created including detailed information for the chasmophytic flora of the Aegean area. More specifically, this database includes all chasmophytic taxa, their chorology, life form, elevational distribution, protection status, and Red List categories as well as their distribution on 120 islands and islets of the Aegean archipelago (including the islands of Crete, Euboea Lesvos, Rodhos, Chios, Samos, Limnos, Naxos, Andros, Thasos, Karpathos, Kos, and many smaller islands and islets) and their distribution in different phytogeographical regions of Greece as defined by Strid and Tan [18]. These phytogeographical regions, according [18], are the island phytogeographical regions of the North Aegean Islands (NAe), West Aegean Islands (WAe), East Aegean Islands (EAe), Kiklades (Kik), and Kriti-Karpathos (KK) as well as the mainland phytogeographical regions of Sterea Ellas (StE) and Peloponnisos (Pe), which host at their eastern parts some Aegean islands and islets (Figure 1).

All available information included in several floristic studies of different areas of the Aegean, mainly in the Atlas of the Aegean Flora $[10,11]$ as well as those in $([6,7,10,11,24,25,37]$, etc.), vegetation plots, phytosociological studies, and in the authors' collections and observations from field work were added to this database.

In the present study, the distinction of the plant taxa is in two categories [24,44] and the analysis of the total chasmophytic flora (TCh) comprises the "obligate" chasmophytes (OCh) and the "facultative" ones (FCh). The database has been enriched with the biological and chorological types of the taxa, their geographical distribution, elevation range of distribution, functional traits, and habitat preferences (for taxa occurring mainly, partially or occasionally on cliffs and rocky slopes). The protection status, according to the Annexes II, IV, and V of the Directive 92/43/EEC and Red List categories according to the European Red List [45], the IUCN Red List, and the Red Data Book of rare and threatened plants of Greece [46-48], have also been added. 


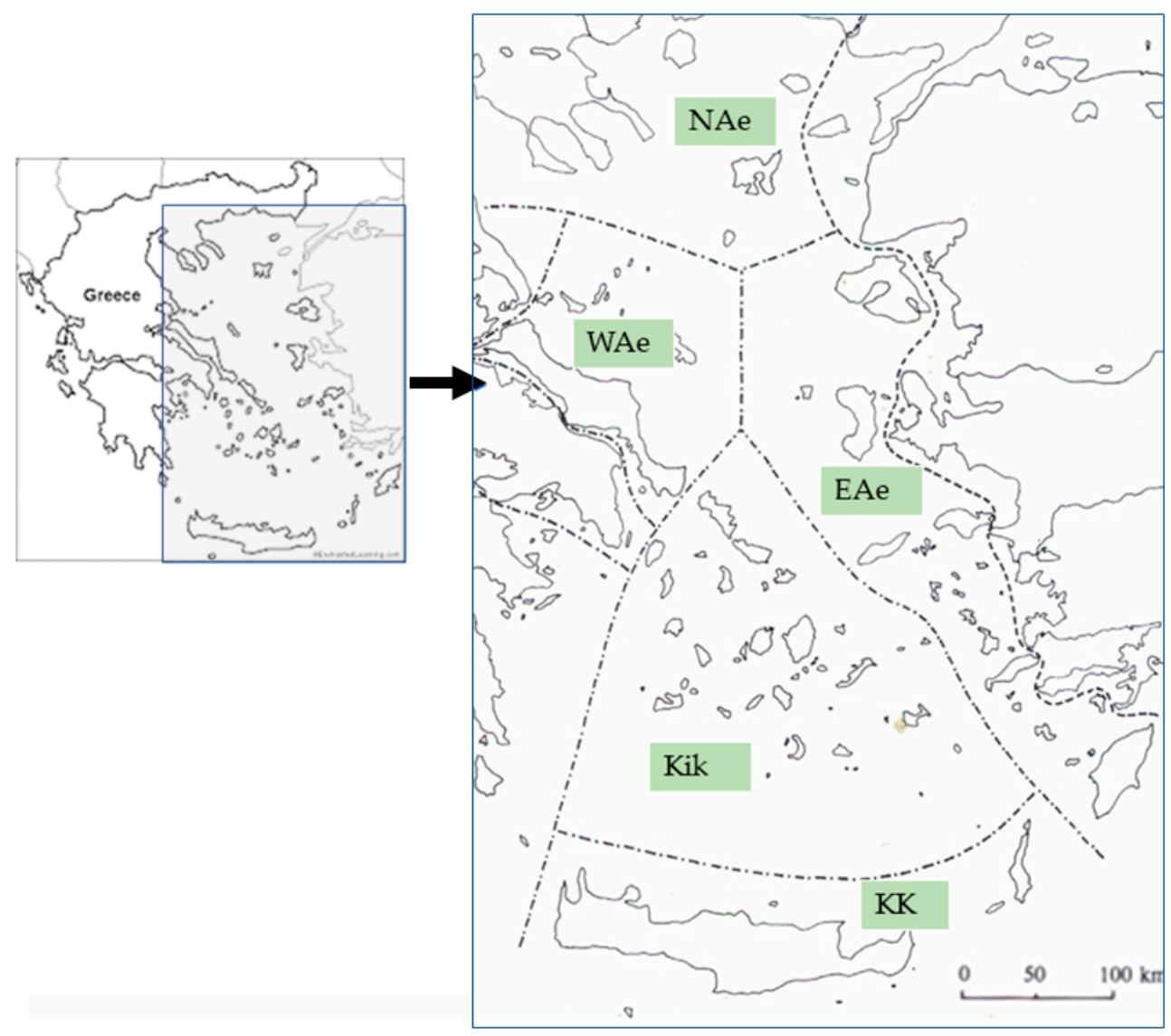

Figure 1. Phytogeographical subdivision of the Aegean archipelago according Strid \& Tan [18]. The five Aegean phytogeographical regions are highlighted: NAe $=$ North Aegean, WAe $=$ West Aegean, EAe $=$ East Aegean, Kik: Cyclades islands, KK = Krti-Karpathos phytogeographical region.

The definition of "taxa" as comprising (1) subspecies and (2) species that have no subspecies as well as of range-restricted taxa as those occurring only along a linear distance not exceeding $500 \mathrm{~km}$, follow Dimopoulos et al. [49]. Life forms, chorological types, habitats, and the distribution of the taxa in the phytogeographical regions of Greece also follow [49]. Geographical and elevational distribution of the taxa follow Strid [10,11].

Different subsets of total chasmophytic flora (TCh) —obligate chasmophytic flora (OCh), facultative chasmophytes (FCh), and endemic obligate chasmophytes (EN) - were used for the analysis. Endemic taxa could be Greek endemics that have a geographical distribution restricted to one or more of the 13 phytogeographical regions of Greece, or Aegean endemic taxa occurring only on one or more of the five Aegean phytogeographical regions.

For the representation of the richest in taxa families in TCh and OCh, the proportions of different life form categories, the representation of different chorological elements in the five phytogeographical regions of the Aegean area, in combination with those in all phytogeographical regions of Greece and the floristic similarity of all phytogeographical regions of Greece concerning TCh, OCh, and endemic chasmophytes, was undertaken using hierarchical cluster analysis (please see Figures 2, 4, 7 and 10, respectively, in [24]).

For the comparisons among the different Aegean phytogeographical regions for TCh, OCh, and EN, we used R programming and the package Vegan [50] to perform the hierarchical cluster analysis, the Sørensen index as the coefficient of similarity, and the Wards criterion as a combination criterion. Hierarchical cluster analysis was also been used to explore the relationship of $\alpha$-diversity and the OCh and EN chasmophytic taxa richness of different elevational gradients (each one of $100 \mathrm{~m}$ ). 
In order to check spatial species turnover of OCh and EN, capture the diversity components, and obtain a comprehensive description of species assemblages, the zeta diversity was also estimated. Zeta diversity links different community patterns together and can be used for identifying community assembly processes, while zeta diversity decline and distance decay are indicative of the role of common and rare species in spatial turnover and their contribution to compositional change [51]. Hui et al. [52] defined zeta diversity as the mean number of shared species in n number of sites that is referred to as the zeta order. The zeta diversity decline (rescaled to $0-1$ ), and the ratio of zeta diversity decline for $\mathrm{OCh}$ and EN vascular plants were estimated using the zetadiv package [53].

\section{Results}

\subsection{Chasmophytic Flora of the Aegean, Species Richness, Life Forms, and Chorology}

The database concerning the total chasmophytic richness (facultative and obligate chasmophytes) of 120 islands and islets of the Aegean area contains 548 species and subspecies representing 455 taxa in total, which are classified into 50 families and 148 genera. A total of 286 species and subspecies, representing 255 taxa, are obligate chasmophytes (OCh) belonging to 31 families and 90 genera.

The most represented family of the total chasmophytic flora (TCh) in the Aegean is Asteraceae with 63 taxa, followed by family Caryophyllaceae with 53 taxa, and Campanulaceae with 40 taxa (Figure 2). Regarding the obligate chasmophytic flora $(\mathrm{OCh})$ as recorded in our database, the richest in taxa families are Asteraceae with 29 taxa, Campanulaceae with 28 taxa, and Caryophyllaceae with 24 taxa. These three families represent $30.3 \%$ of the total chasmophytic taxa registered, $31.7 \%$ of the OCh, and $49 \%$ of the EN. The richest in obligate chasmophytes genera are Campanula, Dianthus, Centaurea, and Silene (Figure 3). These genera represent $27.8 \%$ of the OCh and $35.5 \%$ of EN.

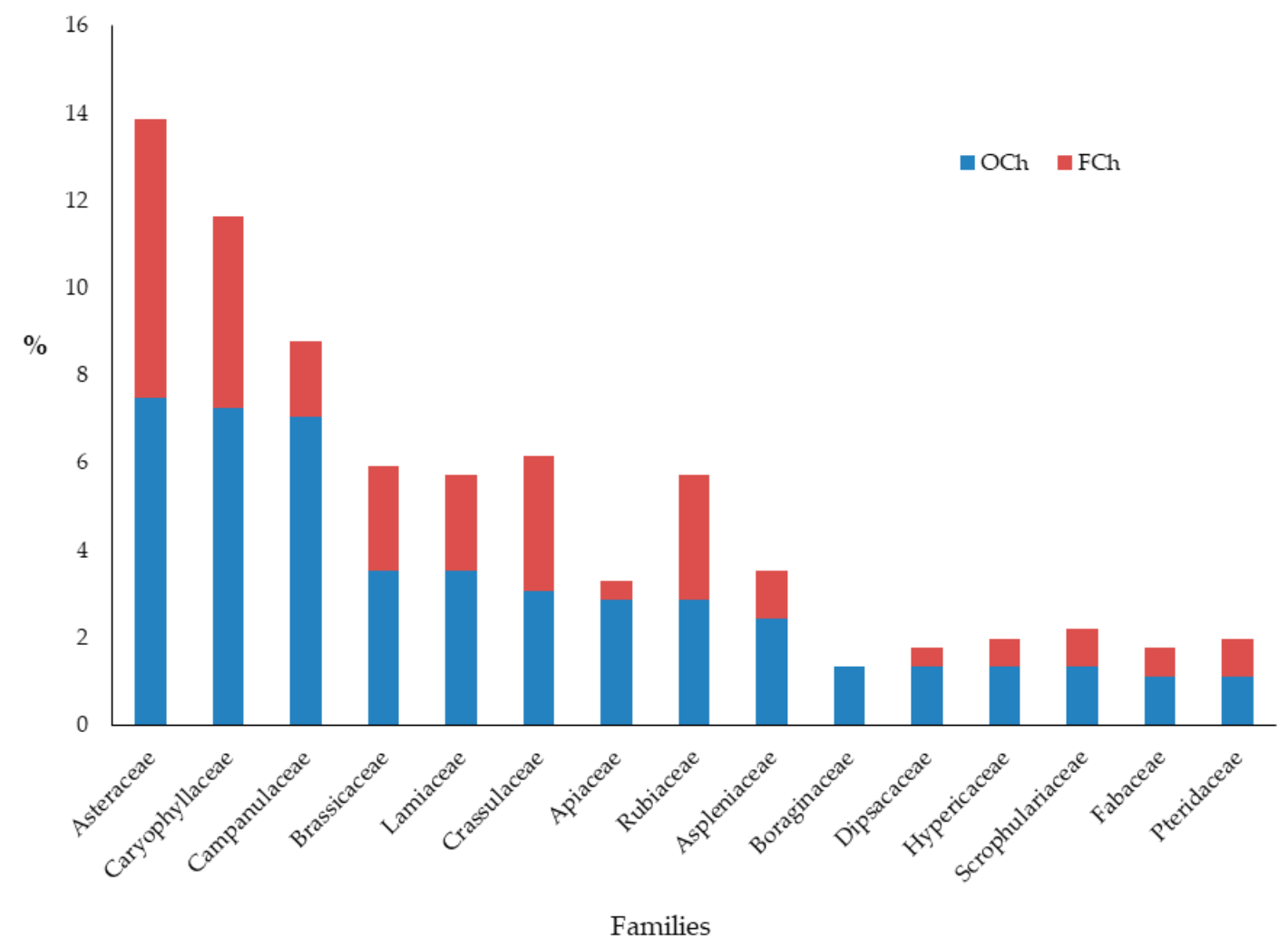

Figure 2. Richest in taxa families of the Aegean chasmophytic flora. Each bar represents the \% representation of each family in the total chasmophytic flora as composed by the proportion of the representation of OCh (obligate chasmophytes) plus FCh (facultative chasmophytes). 


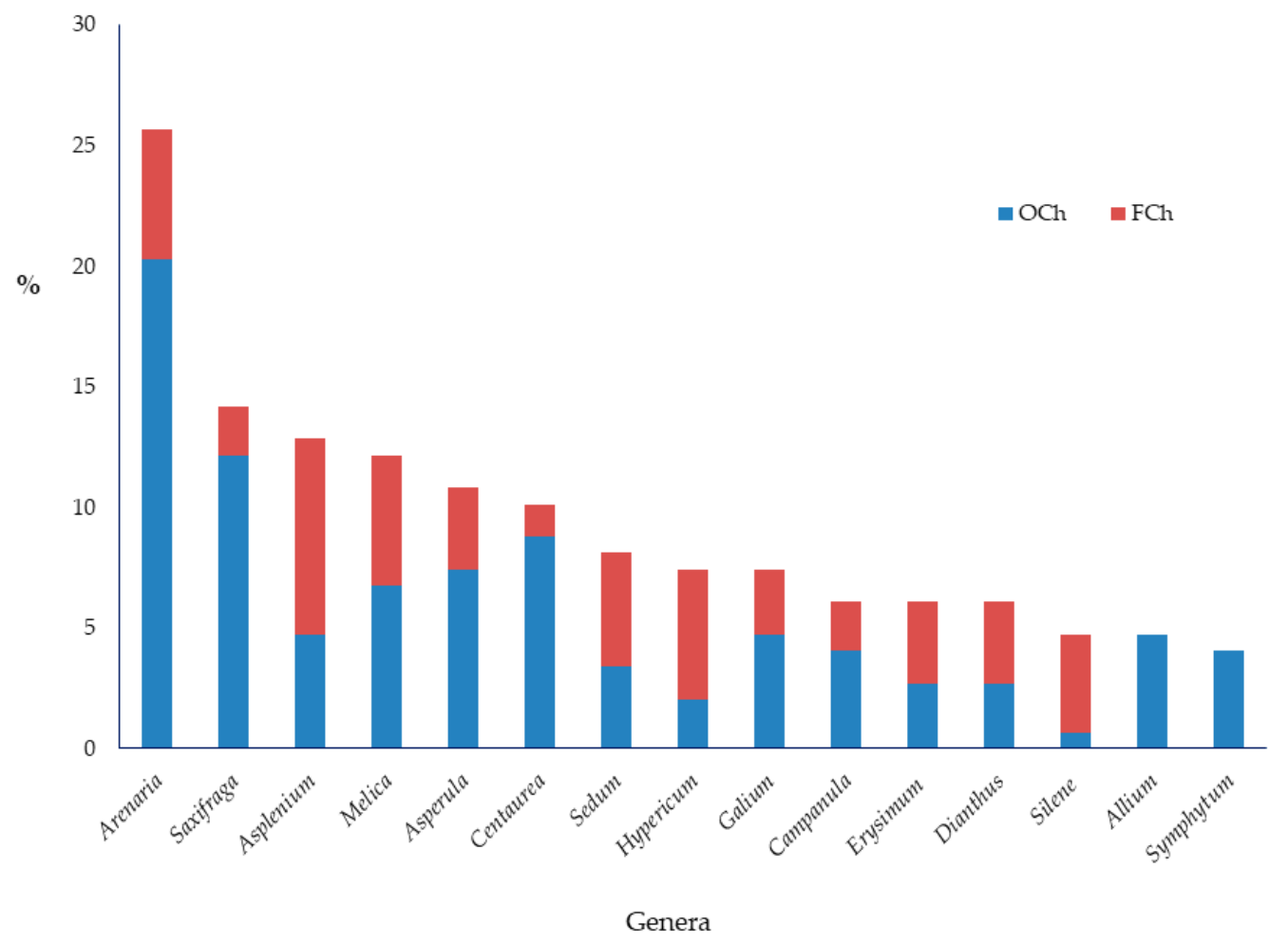

Figure 3. Richest in taxa genera of the Aegean chasmophytic flora. Each bar represents the \% representation of each genus in the total chasmophytic flora as composed by the proportion of the representation of OCh (obligate chasmophytes) plus FCh (facultative chasmophytes).

Figure 4 presents the life-form spectra of the TCh as the sum of the OCh and the facultative ones (FCh). The life form dominating is hemicryptophytes for TCh (78\%) and for OCh (30\%). The second most suitable life form for plant taxa to colonize rocky formations was chamephytes, for all subsets of taxa studied. The proportion of $56.5 \%$ of the EN were hemicryptophytes and $35.5 \%$ were chamephytes.

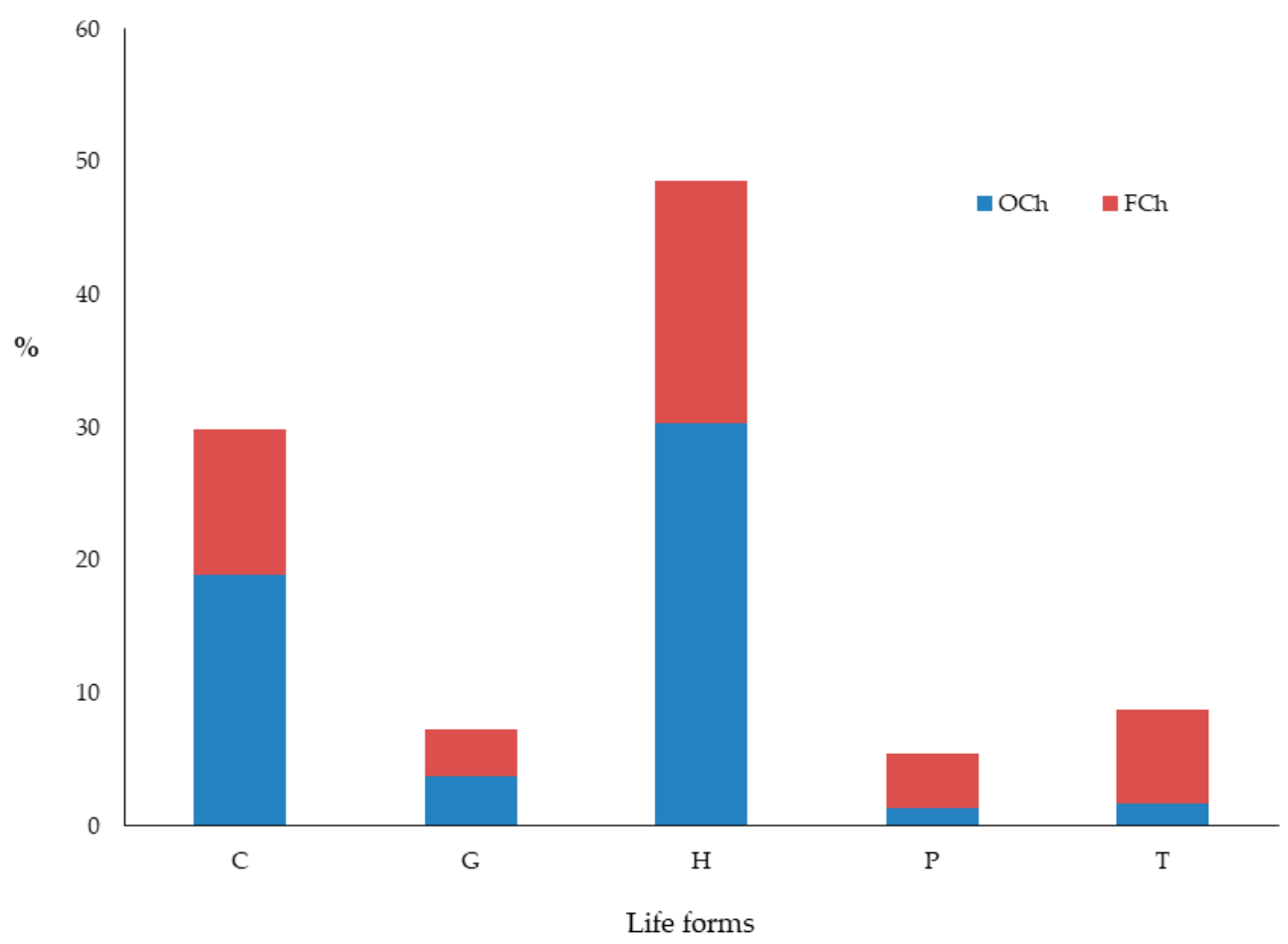

Figure 4. Life form proportions for obligate (OCh) and facultative (FCh) chasmophytes. Abbreviations: $\mathrm{C}=$ chamephyte, $\mathrm{G}=$ geophyte, $\mathrm{H}=$ hemicryptophyte, $\mathrm{P}=$ phanerophyte, $\mathrm{T}=$ therophyte. 
Regarding the chorological analysis, it appears that most taxa belonged to Greek endemics at $51 \%$ TCh, of which $37.14 \%$ was OCh (Figure 5), followed by Mediterranean elements (33.6\% of TCh of which $13.6 \%$ was OCh). Most of the endemic taxa were also range-restricted (96\%). Range-restricted taxa consisted of $56.5 \% \mathrm{TCh}$ and $72.1 \%$ OCh. Endemic obligate chasmophytes (EN) registered on the Aegean islands were also all range-restricted and represented $11.5 \%$ of all Greek endemic taxa: $17.5 \%$ of NAe, $19.3 \%$ of WAe, $20.4 \%$ of Kik, $23.7 \%$ of EAe, and $22.9 \%$ of KK. Most of the EN were neo-endemics $(68.3 \%)$ while $31.7 \%$ were paleo-endemics.

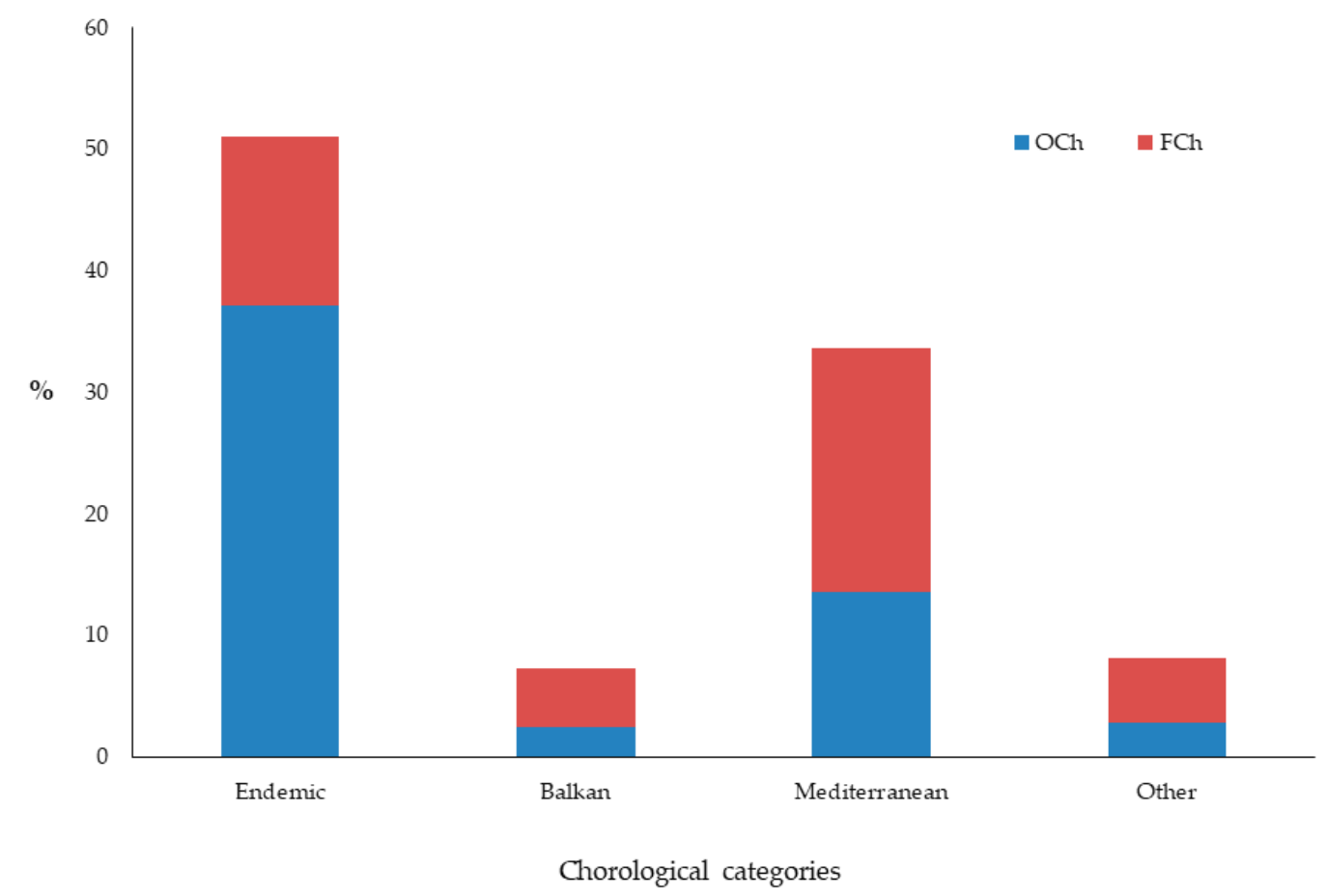

Figure 5. Chorological category proportions for obligate (OCh) and facultative (FCh) chasmophytes.

The most common obligate or facultative chasmophytes registered for the Aegean chasmophytic flora, occurring except in the five Aegean regions as well as in all phytogeographical regions of Greece and so had a frequency rate (F) equal to 1 , represented a very low proportion $(2.7 \%)$ of $\mathrm{OCh}$ and a low one $(10.5 \%)$ of FCh. On the other hand, most of the taxa of both subsets were registered in one of the Aegean phytogeographical regions and had an F equal to 0.077 (Figure 6), representing $54.9 \%$ of OCh and $30 \%$ of FCh. Among the obligate chasmophytes, most endemic ones had a very low frequency in the phytogeographical regions as well as on Aegean islands. A total of $69.8 \%$ of the OCh registered for the Aegean area were only found in the Aegean (5.5\% only on one Aegean phytogeographical region, 26 on two, 11 on three, and one on four of the Aegean phytogeographical regions), $46.4 \%$ were registered on one of the 120 islands and islets, and $43.4 \%$ on two to 10 of the 120 . A total of $57.25 \%$ of them were endemic and range-restricted taxa.

Concerning their protection status, five chasmophytic taxa of the Annexes II and IV of the Directive 92/43/EEC [54] belong to the cliff flora, four of which are of priority for protection, Bupleurum kakiskalae Greuter, Hypericum aciferum (Greuter) N. Robson, Convolvulus argyrothamnos Greuter, Origanum dictamnus L., and Asyneuma giganteum (Boiss.) Bornm. Seven taxa are included in the IUCN (International Union for the Conservation of Nature) Red List of threatened species [55], of which three are critically endangered (CR), one is vulnerable (VU), and one endangered (EN). Thirty-eight endemic chasmophytic taxa are included in Phitos et al. $(1995,2009)$, of which six are considered as critically endangered (CR), three as endangered (EN), and 22 as vulnerable (VU). Additionally, Bupleurum kakiskalae and Convolvulus argyrothamnos registered on Crete, Allium calamarophilon on Euboea, and Aethionema retsina on Skyros and Skyropoula are among the top 50 Critically Endangered island plant taxa of the Mediterranean [56]. 


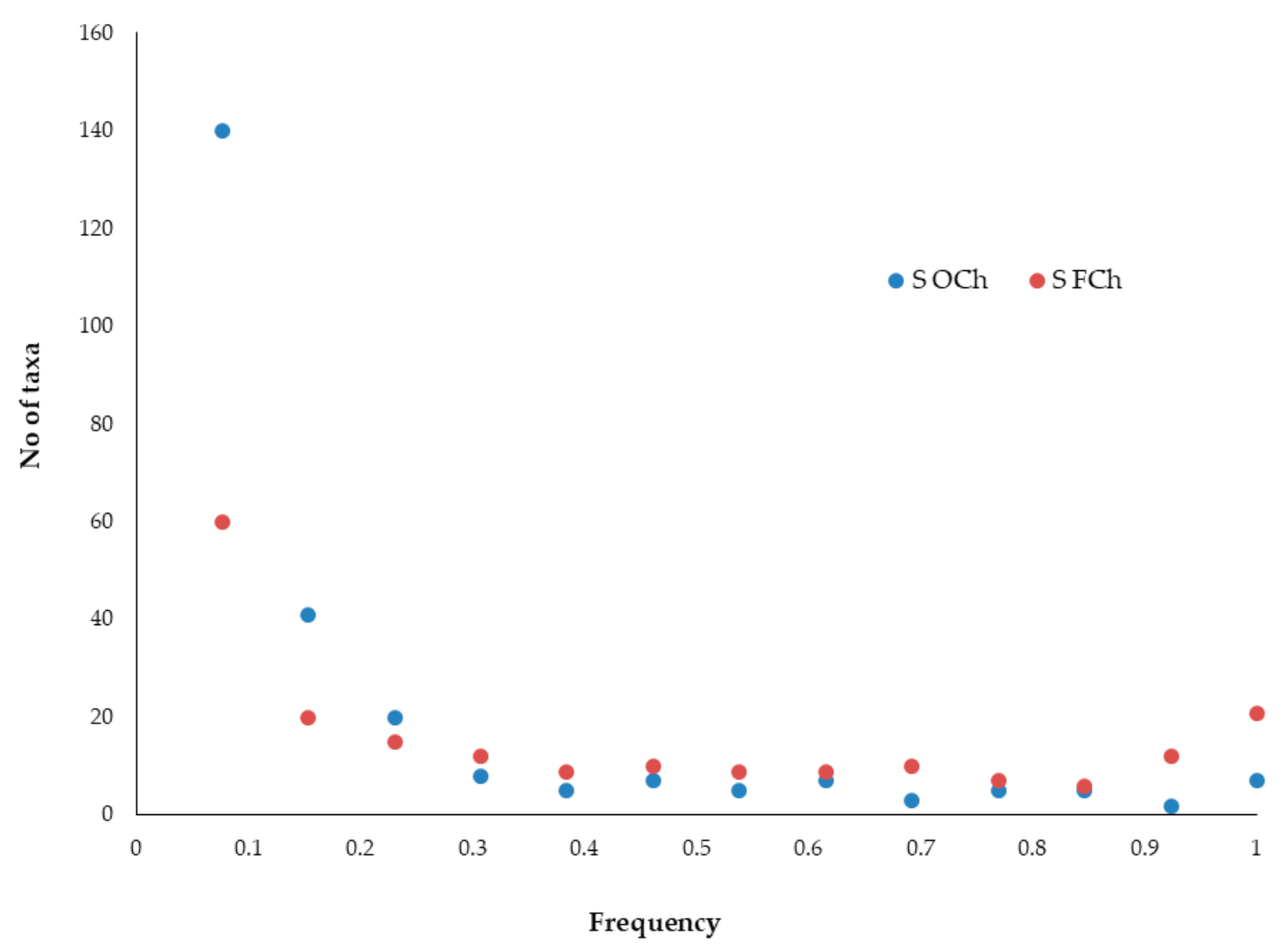

Figure 6. Frequency of obligate (OCh) and facultative (FCh) chasmophytes registered in the Aegean area, in the five Aegean and in all phytogeographical regions of Greece. $\mathrm{S}=$ number of taxa.

Figure 7 presents the rather low floristic similarity of the chasmophytic flora among the five island phytogeographical regions of the Aegean for TCh, OCh, and EN. When examining TCh, NAe was more similar to KK, WAe to EAe, and Kik seemed to be rather independent concerning its chasmophytic flora, which was more or less the case for OCh (Figure 7a,b). Concerning EN, there were separate groups: Kik was more similar to EAe, and KK first to WAe and then to NAe (Figure 7c).

\subsection{Elevational Gradients and Spatial Turnover of Chasmophytic Diversity}

Boxplots of the minimum and maximum elevational distribution as well as the elevational ranges of OCh, FCh, and EN are presented in Figure 8. Figure 9a shows that OCh richness and EN-richness are strongly correlated with elevation, while FCh is significantly correlated with elevation $\left(R^{2}=0.866\right.$, 0.861 and 0611 , respectively). Figure $9 \mathrm{~b}$ presents the elevational gradients of obligate chasmophytes that are present at elevation $>1000 \mathrm{~m}$. It is important to remark that some obligate chasmophytes have a restricted elevational range of $100 \mathrm{~m}, 200 \mathrm{~m}$, or $300 \mathrm{~m}$ and are found only at elevations $>1000 \mathrm{~m}$ while others have an extended elevational range of, for example, more than $1200 \mathrm{~m}$ from sea level to elevation $>1000 \mathrm{~m}$. There is an increase of obligate chasmophytic taxa richness from sea level to $1400 \mathrm{~m}$, a slight decrease up to $1600 \mathrm{~m}$, a slight increase again from 1700 to 1800 , and then another decrease, presenting a hump-shaped pattern. 
Total chasmophytic flora $(\mathrm{TCh})$

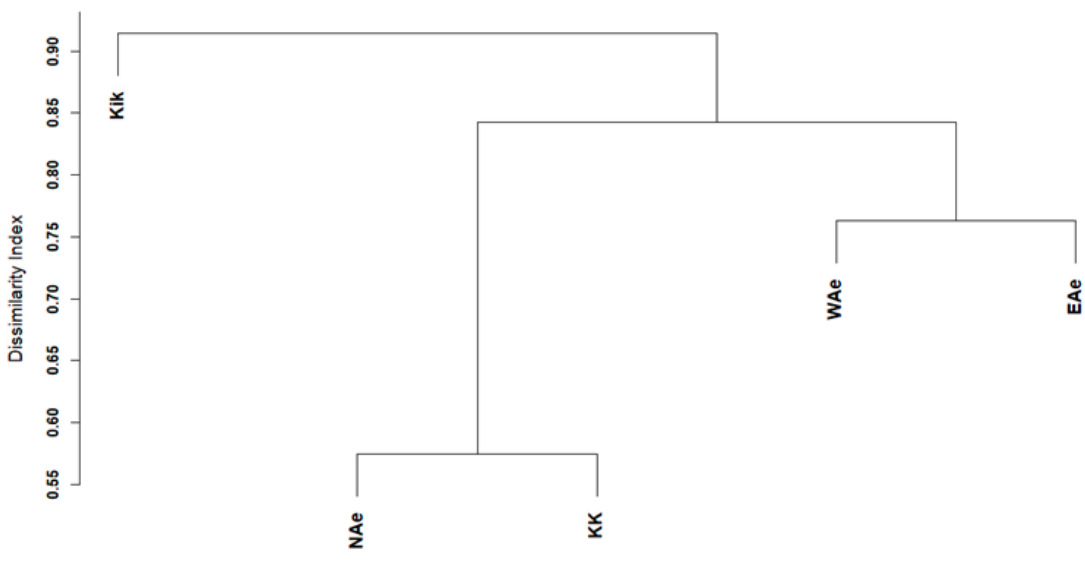

hclust (", "ward.D")

Obligate chasmophytes $(\mathrm{OCh})$

b

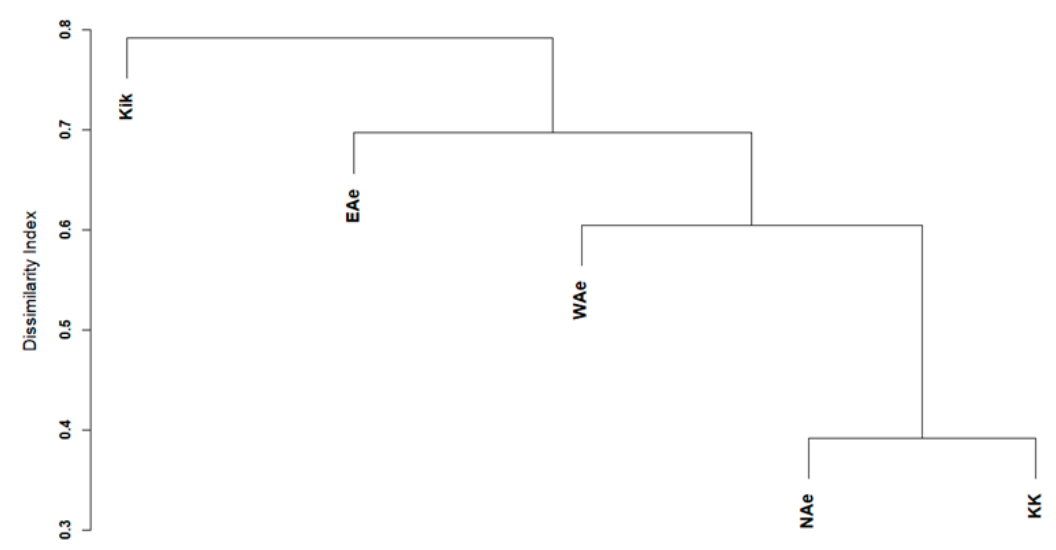

hclust (", "ward.D")

Endemic obligate chasmophytes (EN)

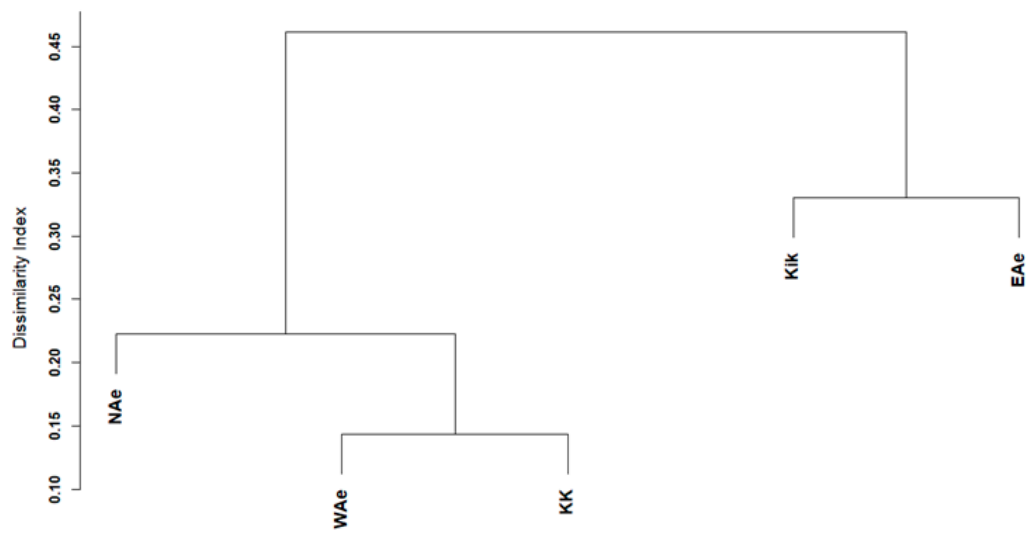

hclust (" "ward.D")

Figure 7. Hierarchical cluster analysis showing floristic similarity of the chasmophytic flora among the 5 island phytogeographical regions of the Aegean for (a) total (TCh), (b) obligate (OCh), and (c) endemic obligate $(\mathrm{EN})$ chasmophytes. Abbreviations: NAe = North Aegean, WAe = West Aegean, $\mathrm{EAe}=$ East Aegean, Kik: Cyclades islands, $\mathrm{KK}=$ Crete-Karpathos phytogeographical region . 


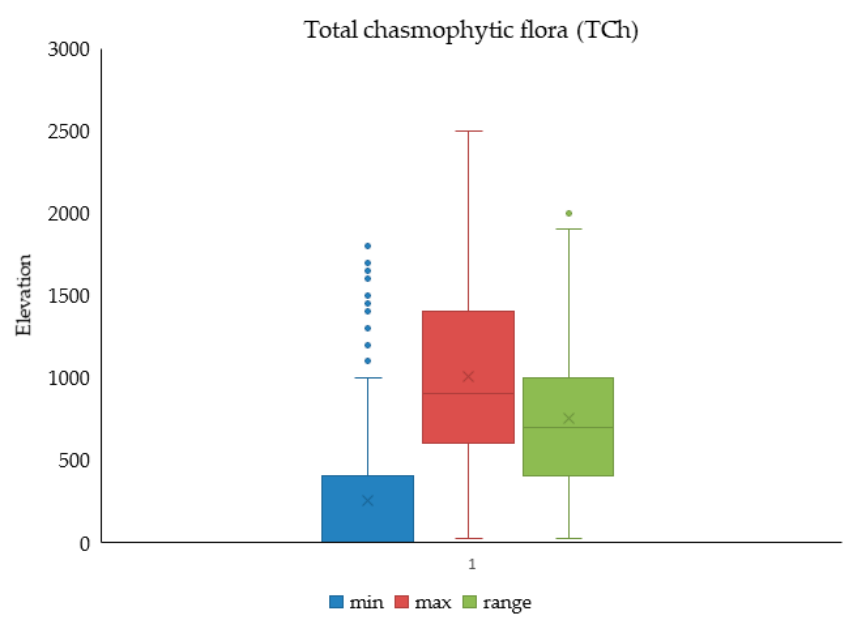

a

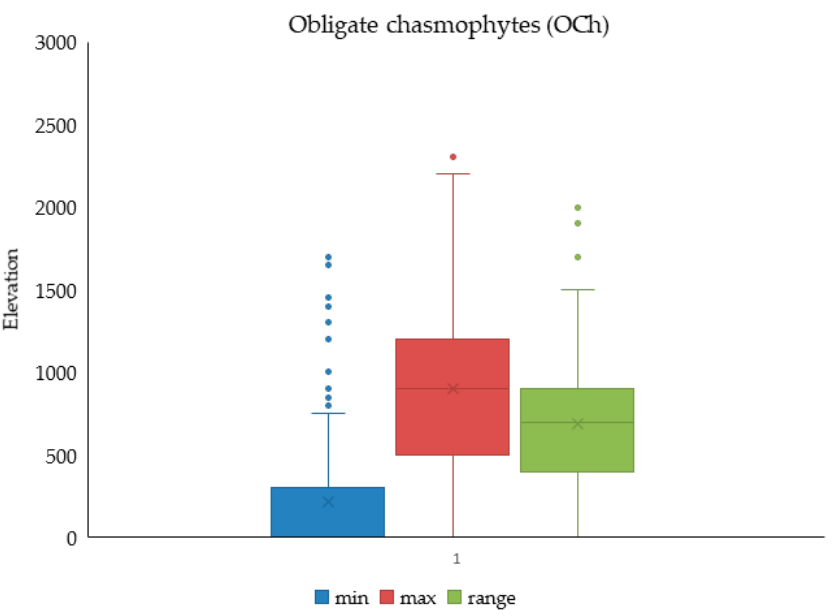

b

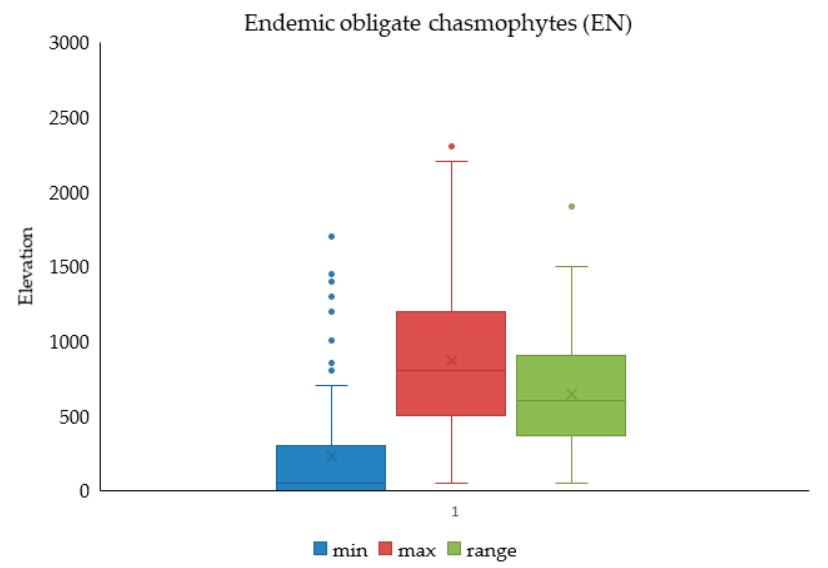

Figure 8. Boxplots of the minimum and maximum elevational distribution as well as the elevational ranges of (a) total (TCh), (b) obligate (OCh), and (c) endemic obligate (EN) chasmophytes of Crete. The horizontal line denotes the mean values, the box indicates the first and third quartiles, and outliers are plotted as individual points. 

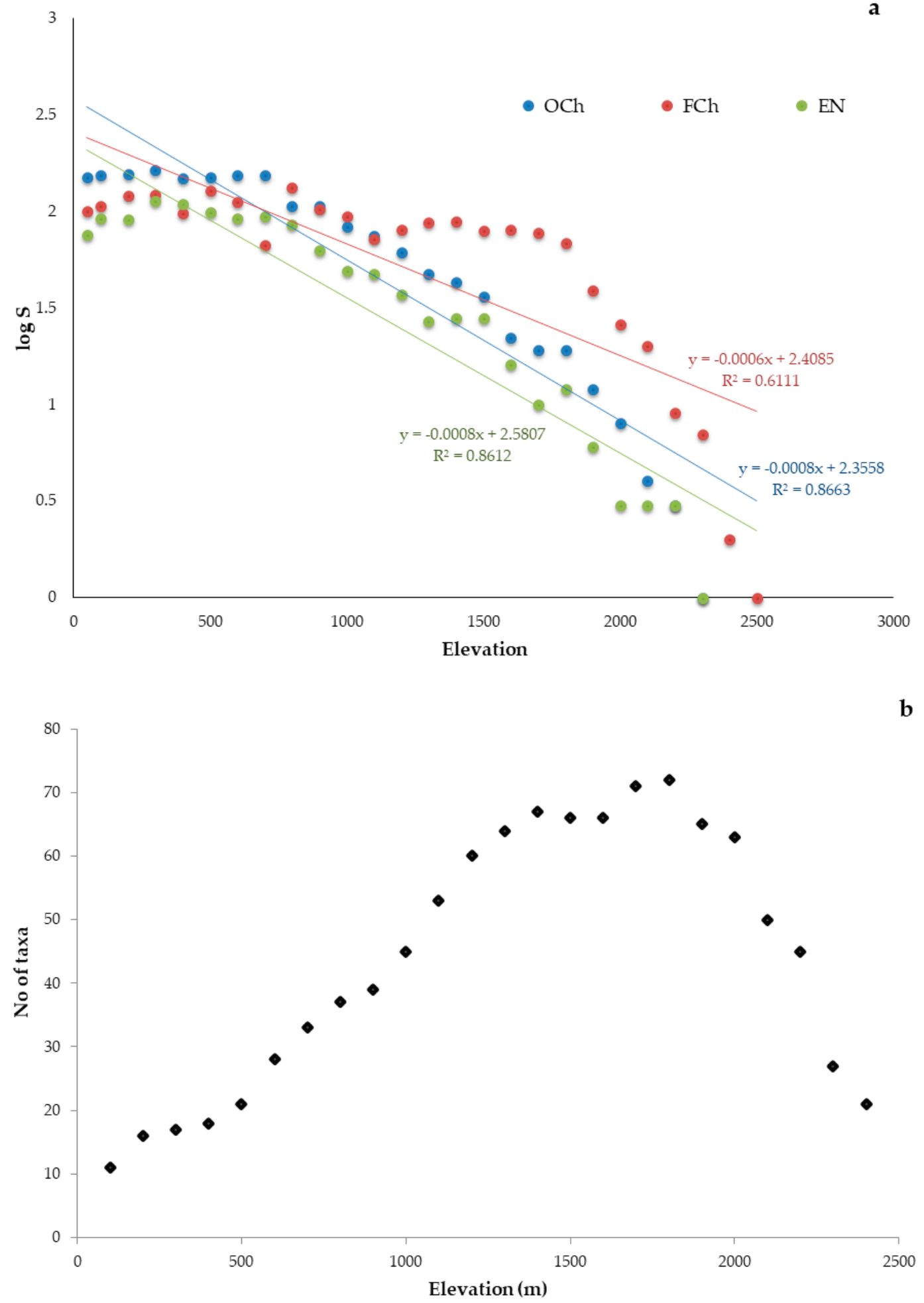

Figure 9. (a) Elevational gradient of obligate ( $\mathrm{OCh}$ ), facultative (FCh), and endemic obligate chasmophytes (EN) in the Aegean area. $\mathrm{S}=$ number of taxa. Trend lines and equations were set by simple regressions $(p<0.001)$ and $(\mathbf{b})$ Elevational gradient of obligate chasmophytes $(\mathrm{OCh})$ that are distributed at elevation $>1000 \mathrm{~m}$. Black circles $=$ number of OCh at elevational gradients of $100 \mathrm{~m}$.

Floristic similarity of the different elevational gradients was examined using hierarchical cluster analysis of OCh and EN taxa (Figure 10). For OCh, there were two main groups: one with chasmophytic taxa richness on gradients of low elevation to 1100 a.s.l., and the other at medium to high elevations. 
Dissimilarity among the low, medium, and high elevational gradients increased and was revealed when the analysis was conducted using EN taxa. The elevational range profile of the OCh showed that $21.9 \%$ had wide elevational ranges along the gradient $(\geq 1000 \mathrm{~m})$, and $37.6 \%$ had elevational ranges $\leq 500 \mathrm{~m}$. For EN, the elevational range profile was different as $45.7 \%$ of the taxa had a narrow elevational range profile $(\leq 500 \mathrm{~m}), 30.5 \%$ between 700 and $900 \mathrm{~m}$, and $11.6 \%$ had a wide one $(\geq 1000 \mathrm{~m})$.

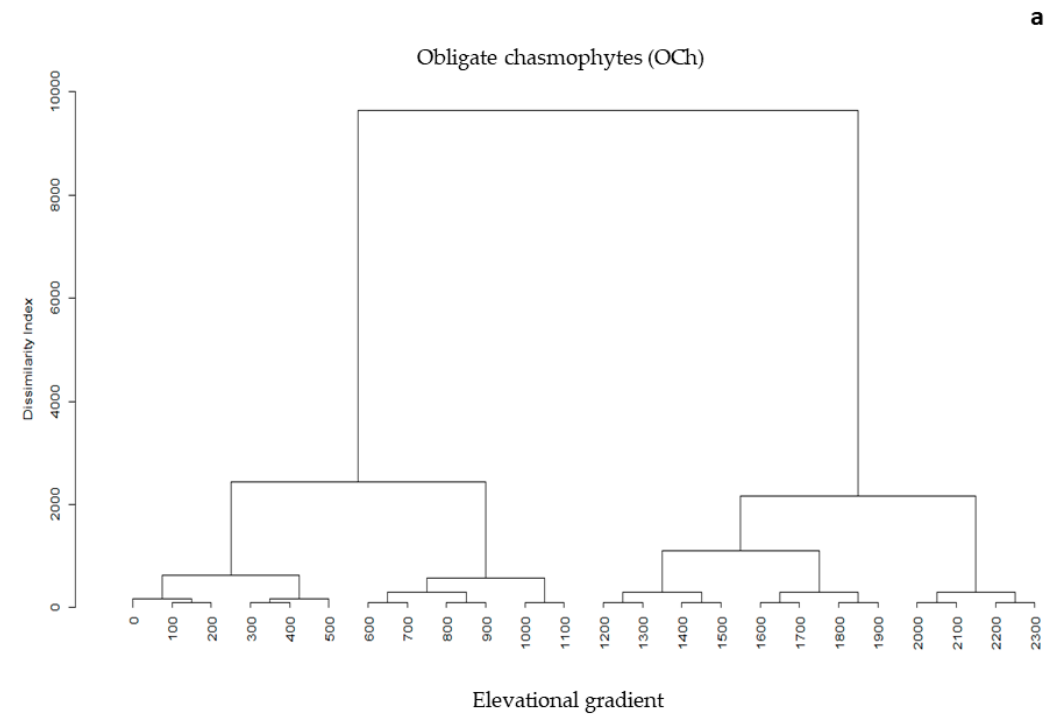

Endemic obligate chasmophytes (EN)

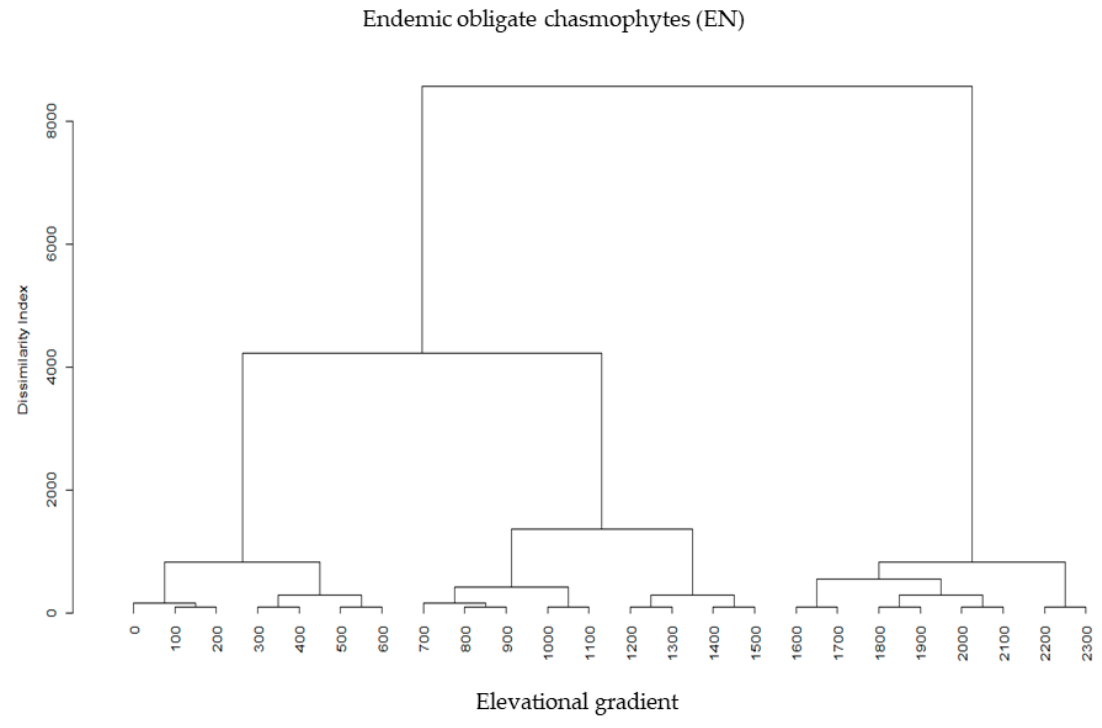

Figure 10. Hierarchical cluster analysis showing floristic similarity of the different elevational gradients of (a) obligate (OCh) and (b) endemic obligate (EN) chasmophytes. Sørensen index and the Wards criterion have been used for the similarity coefficient and the combination criterion, respectively.

Concerning species spatial turnover along elevational gradients, the zeta diversity decline with zeta order was sharp, indicating that the number of OCh declined sharply from zeta order 1 to 2 and then softer to 4 , after which it was stable (Figure 11). For EN, the retention rate was less sharp, indicating that the number of shared endemic obligate chasmophytes decline was less sharp as more elevational gradients were included for the zeta diversity estimation (Figure 11). The relationship of the zeta ratio with order showed that the OCh retention rate decreased sharply starting from order 1, while the EN retention rate increased sharply up to the 5 and 6 zeta order (indicating not common taxa, rare taxa), 
reached a rather rough plateau to 8 zeta order, and then decreased to higher zeta orders (indicating common taxa with a high frequency of presence).
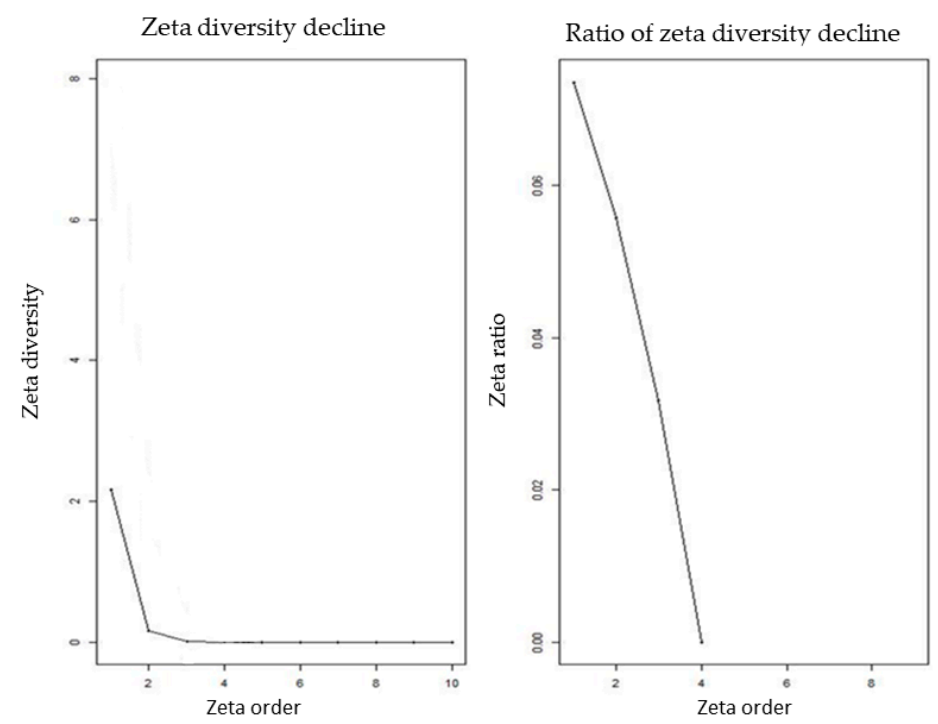

a
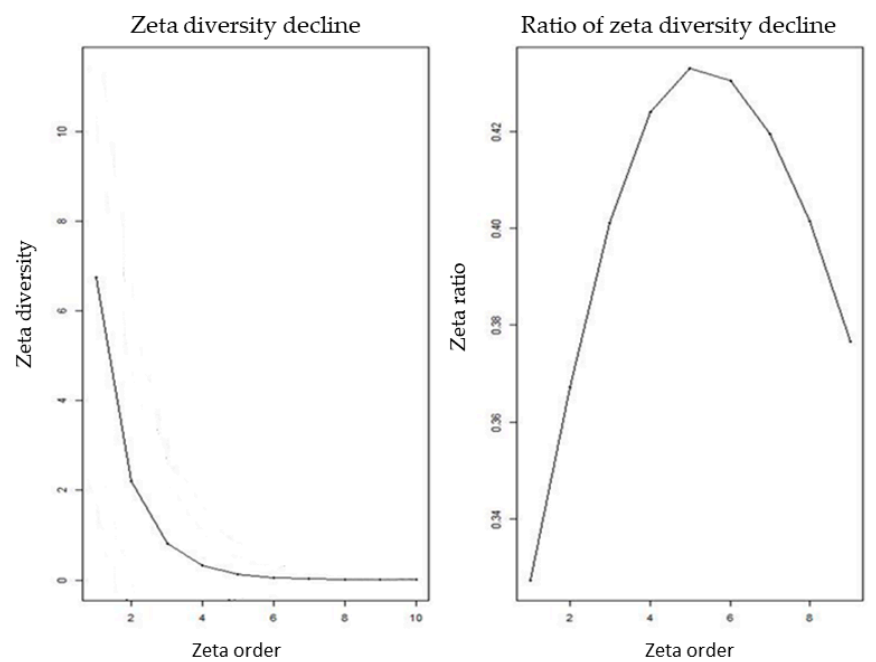

b

Figure 11. The zeta diversity decline and ratio of zeta diversity decline for (a) obligate (OCh) and (b) endemic obligate (EN) chasmophytes.

\section{Discussion}

\subsection{Chasmophytic Flora of the Aegean, Species Richness, Life Forms, and Chorology}

On island archipelagos, species distribution depends on immigration, extinction, and speciation, and it is not an easy task to separate the effects and interactions of these processes [57].

As pointed out by many studies, understanding which specific features affect native plant assemblages is even more important when considering the increasing global biodiversity loss, and most important of all are the endemics, the most valuable botanical resources. Understanding the ecological characteristics of narrow endemic species (i.e., species with a restricted distribution area) is crucial for their conservation, and for research on the evolutionary processes leading to endemism [22].

Cliffs in the Mediterranean are considered refugia for plant species with unique species composition [58]. Vertical cliffs and rocky habitats in a landscape contribute to the isolation of open habitats and increase fragmentation among patches, but also consist of habitat islands, often isolated, 
which are themselves separated from each other by dispersal barriers, creating divergence between resident populations [59] and having the potential to harbor relatively high levels of endemism [60].

The diversity of endemic and range-restricted taxa is more distinct in habitats isolated as cliffs and rocky habitats that host $22.9 \%$ of the endemics of the Greek vascular flora $[49,61]$. The chasmophytic richness of the Aegean area represents 57.6\% of the Greek chasmophytic richness. The richest in taxa families Asteraceae, Campanulaceae, and Caryophyllaceae present high endemic taxa proportions of the total cliff flora and of the obligate chasmophytes, as is in general terms, the pattern of the whole Greek and chasmophytic flora [24], as also observed in the Mediterranean islands of Corsica [62] and Sardinia [63] and in other Mediterranean type climate provinces [64]. The Mediterranean Basin is considered the center of species diversity for the Centaureinae of Asteraceae $[65,66]$ and Centaurea is one of the richest in taxa genera of obligate chasmophytes in the Aegean area as well as in Greece. Caryophyllaceae show active endemism in Greece [67] and has large concentrations of genera in the Mediterranean Basin [68] as the genera of Dianthus and Silene, which are among the richest of the obligate chasmophytic flora of the Aegean area. The Mediterranean Basin is the evolutionary center of all the Greek genera of Campanulaceae [69], and Campanula shows a high degree of Aegean chasmophytic richness $(20.3 \%)$ and endemism $(15.4 \%)$ as well as of Greek richness and endemism [70]. Cretan Campanula species endemism may have been more widespread in the past, but is now restricted to inaccessible areas as cliffs, probably as a result of human pressure [44].

Hemicryptophytes dominate among chasmophytes, followed by chamephytes and the functional attributes of these life forms enable chasmophytes to withstand extreme conditions prevailing on cliffs [70]. The attributes of hemicryptophyte offer them some protection from the environmental conditions prevailing at higher elevations and a better odd of survival at low and intermediate elevations where the lengthened growth period allows for lateral growth [71,72]. Chamephytes seem to cope better in mountainous environmental conditions than other life forms [73] and to complete their life cycle successfully, even in the short growing periods observed at high elevations [74]. The importance of chamephytes in cliff communities is far in excess of that found in the general Mediterranean and Aegean spectra (where mainly therophytes predominate), since chamephytes (predominantly suffruticose) are the dominant life forms, especially on vertical rocks and its relative abundance is apparently directly proportional to the steepness of the rock [13].

The highest (in KK) and the lowest (in NAe) endemism rate among the Greek floristic regions were within the Aegean area [49,61]. A total of $66.3 \%$ of the obligate chasmophytes in the Aegean area were endemics, representing $11.5 \%$ of all Greek endemic taxa and $22.8 \%$ of all endemic taxa registered in the Aegean. Endemic obligate chasmophytes, of which more than their two thirds are neo-endemics, also represent $17.5-23.7 \%$ of the endemic taxa registered in the five Aegean phytogeographical regions. Panitsa and Kontopanou [24] mentioned that dissimilarity increased among the different phytogeographical areas and was revealed when the analysis used endemic and range-restricted taxa. Analysis of the patterns of endemism and range-restrictedness rates of the Aegean phytogeographical regions showed that KK presented a high endemism rate combined with a high rate of range-restrictedness, and so can be regarded not only as a speciation hotspot, but also as the richest island phytogeographical area in the Aegean, followed by Kik, which emerged as the second richest Aegean phytogeographical region in terms of Greek and Aegean rates [75].

\subsection{Elevational Gradients and Spatial Turnover of Chasmophytic Diversity: Monitoring Insights}

Kallimanis et al. [76] found that neo-endemics, as a proportion of the islands' flora, is associated only with the islands' maximum elevation and that neoendemic species richness is also strongly correlated to island area and diversity of geological substrate, indicating that an island's habitat heterogeneity is the main environmental driver of speciation. The effect of large-scale topography such as mountain ranges on patterns of species richness, speciation rates, and endemism are increasingly well documented $[39,42,57,77-80]$, but the direct effect of local topography such as ravines is less well 
understood [60], although areas with larger variation in elevation are thought to have higher speciation and endemism rates [81].

Mountainous topography favors high endemic species richness [82]. Rechinger [83] stated that Aegean endemics are mainly ancient mountain endemics with distribution areas older than the current land/sea distribution, since the present-day Aegean Islands were mountaintops in the geological past. Area and elevation are the most important factors affecting plant diversity patterns in the Aegean and have a high significance in the differentiation of Aegean plants [6] (and references therein). In the Aegean area, there is a predominance of local endemics restricted or occurring at the thermo-Mediterranean zone, which decreases as the coverage in high mountains increases [70]. Habitat diversity, of which elevation is another dimension, is the main factor affecting plant species diversity (including single island endemics) on East Aegean islands, except the Aegean endemics that are better predicted by elevation [84]. On a global scale, archipelago endemics have been shown to increase with elevation [39], but looking more closely at small-scale topographic variation may reveal more intricate patterns of endemism [60]. Drivers affecting plant diversity patterns along elevational gradients on the continental island of Crete seem to be combined, each one with different intensity and duration of influence, depending largely on historical parameters [37]. Hierarchical cluster analysis showed that OCh and EN species richness dissimilarity among the low, medium, and high elevational gradients was prominent and increased with elevation. Elevational range profiles showed that a high proportion of OCh $(37.6 \%)$ and a higher one of EN (45.7\%) had narrow elevational ranges $(\leq 500 \mathrm{~m})$. Retention rate and pattern of zeta diversity decline with zeta order reflected obligate chasmophytes patterns and their elevational range size. As zeta order increased, less obligate chasmophytes were shared between elevational gradients and this was more discrete in low orders of zeta, reflecting the contribution of rare species to the observed pattern [85].

High chasmophytic diversity results in a chasmophytic flora varied along different environmental gradients, and temperature can be identified as the factor most strongly correlated with the variation of rock-face vegetation [86]. Global warming is severely impacting species distributions and is believed to be a major driver of species extinctions, since in high altitude regions, an increase in species richness as a result of upward movement of generalist species may undergo local extinction of endemic specialists and rare plants as the endemic obligate chasmophytes [87-89] (among others).

In the framework of the Natura 2000 network, monitoring of the habitat type 8210: "rocky slopes with chasmophytic vegetation" and of the endemic obligate chasmophyte island plants included in Annexes II and IV of the Directive is taking place. It would be necessary to continue and reinforce in situ studies for the narrow distributed endemic obligate chasmophytes species in order to follow the conservation status of their population(s) and evaluate the need to carry out reinforcement plans ae well as additionally ensuring the ex situ long-term conservation of seeds in gene banks. Monitoring of microhabitats inhabited by endemic obligate chasmophytes, strictly adapted to concrete ecological requirements like cliffs and rocks is also important, in order to assure the conservation of their populations.

Islands are underrepresented in global biodiversity monitoring schemes already in place, reflecting broader gaps in global biodiversity datasets [90] and only a few long-term projects have quantified the impact of global change drivers of island ecosystems such as the Global Observation Research Initiative in Alpine Environments [91], which includes monitoring a few island mountain systems (among which are those of the island of Crete). Borges et al. [90] proposed an integrated Global Island Monitoring Scheme (GIMS) that is accurate and sustainable in the long-term, includes protocols that can be applied to both 'short-term' and 'long-term', continuous monitoring programs, assesses long-term effects of key global change drivers, and generates data to inform biodiversity conservation and ecosystem management. Sampling and direct measurements using indicators of habitat quality along an elevational transect allows for the evaluation of the impact of climate change at a mesoclimatic scale by investigating, for example, shifts in species abundances and distributional ranges in relation to key environmental gradients such as temperature and precipitation [92]. 
Climate warming in combination with decreasing precipitation are expected to result in biodiversity losses since colonization of high-elevation habitats by usually more widespread species of lower altitudes will threaten cryophilic species, especially the endemic ones, and this deserves fostering comparative monitoring activities in Mediterranean regions of higher elevation [93]. The presence of an ongoing process of homogenization and biodiversity loss has been documented and could be interpreted as an alarming signal [94]. For these reasons, monitoring is important for the management and conservation of narrow endemic specialist taxa as the obligate chasmophytes. As for habitat types such as "8210" and species included in Annexes I, II, IV, and V of Directive 92/43/EE, conservation objectives should be based on their ecological requirements and reflect the importance of the site for the maintenance at a favorable conservation status of the habitat types and species populations, and address the pressures and threats of degradation to which the habitats and species on the site are exposed [95]. Effective conservation of rare plant species requires a detailed understanding of their unique distributions and habitat requirements to identify conservation targets [96]. Considering the pressing current and future environmental change, effective management will not be possible without proper long-term monitoring of island ecosystems and specialized habitats and species [90].

\section{Concluding Remarks}

Cliffs as habitat islands on the Aegean islands, consist of refugia from unfavorable climatic change and from competition with other species for many endemic and rare plants, specialized to their extreme ecological conditions. Chasmophytic diversity is very rich in the Aegean area. Obligate chasmophytes are strongly related to elevational gradients and most of them are range-restricted Aegean or Greek endemics. High chasmophytic diversity results in a floristic composition varied along different environmental gradients. Endemic obligate chasmophytes, adapted to high elevational gradients and with narrow elevational range, will be threatened by climate warming combined with decreasing precipitation, which will provide opportunities for more widespread taxa to colonize higher elevational gradients and their habitats, and press their vulnerable populations. Understanding the distributions of narrow endemic obligate chasmophytes and their habitat requirements will drive effective monitoring and conservation objectives.

Author Contributions: Conceptualization, M.P. and A.K.; methodology, M.P. and A.K.; software, A.K.; validation, M.P. and A.K.; formal analysis, A.K. and M.P.; investigation, A.K. and M.P.; resources, A.K.; data curation, A.K. and M.P.; writing-original draft preparation, M.P. and A.K.; writing — review and editing, M.P. and A.K.; visualization, M.P. and A.K.; supervision, M.P. All authors read and approved final version of the manuscript.

Funding: This research received no external funding.

Acknowledgments: The authors would like to thank the two anonymous reviewers for their valuable comments and suggestions and S. Gioldasis, IT Engineer, MSc, for his kind technical support.

Conflicts of Interest: The authors declare no conflict of interest.

\section{References}

1. Médail, F.; Quézel, P. Hot-spots analysis for conservation of plant biodiversity in the Mediterranean Basin. Ann. Mo. Bot. Gard. 1997, 84, 112-127. [CrossRef]

2. Blondel, J.; Aronson, J.; Bodiou, J.Y.; Bœuf, G. The Mediterranean Region: Biological Diversity in Space and Time, 2nd ed.; Oxford University Press: Oxford, UK, 2010.

3. Triantis, K.A.; Mylonas, M. Greek islands, biology. In Encyclopedia of Islands; Gillespie, R., Glague, D.A., Eds.; University of California Press: Berkeley, CA, USA, 2009; pp. 388-392.

4. Strid, A. Phytogeographia Aegaea and the Flora Hellenica Database. Annalen Naturhistorischen Museums in Wien 1996, 98 (Suppl. B), 279-289.

5. Sfenthourakis, S.; Triantis, K.A. The Aegean archipelago: A natural laboratory of evolution, ecology and civilisations. J. Biol. Res. Thessalon. 2017, 24, 4-16. [CrossRef] [PubMed] 
6. Panitsa, M.; Kagiampaki, A.; Kougioumoutzis, K. Plant diversity and biogeography of the Aegean archipelago: A new synthesis. In Biogeography and Biodiversity of the Aegean; In Moysis, M., Pafilis, P., Parmakelis, A., Poulakakis, N., Sfenthourakis, S., Triantis, K., Eds.; Broken Hill Publishers Ltd.: Nicosia, Cyprus, 2018.

7. Kougioumoutzis, K.; Tiniakou, A. Ecological factors and plant species diversity in the South Aegean Volcanic Arc and other central Aegean Islands. Plant Ecol. Divers. 2014, 8, 173-186. [CrossRef]

8. Uotila, P. Fifty years of mapping the Balkan flora for Atlas Florae Europaeae. Bot. Serbica 2017, 41, $163-175$.

9. Kougioumoutzis, K.; Valli, A.T.; Georgopoulou, E.; Simaiakis, S.M.; Triantis, A.; Trigas, P. Network biogeography of a complex island system: The Aegean Archipelago revisited. J. Biogeogr. 2017, 44, 651-660. [CrossRef]

10. Strid, A. Atlas of the Aegean Flora; Part 1: Text \& Plates; Botanischer Garten und Botanisches Museum Berlin-Dahlem: Berlin, Germany, 2016; Volume 33, pp. 1-1578.

11. Strid, A. Atlas of the Aegean Flora; Part 2: Maps; Botanischer Garten und Botanisches Museum Berlin Dahlem: Berlin, Germany, 2016.

12. Larson, D.W.; Matthes, U.; Kelly, P. Cliff Ecology: Pattern and Process in Cliff Ecosystems; Cambridge University Press: Cambridge, UK, 2000.

13. Davis, P.H. Cliff vegetation in the eastern Mediterranean. J. Ecol. 1951, 39, 63-93. [CrossRef]

14. Snogerup, S. Evolutionary and plant geographical aspects of chasmophytic communities. In Plant Life of South-West ASIA; Davis, P.H., Harper, P.C., Hedge, I.C., Eds.; Botanical Society of Edinburgh: Edinburgh, Scotland, 1971; pp. 157-170.

15. Thompson, J.D. Plant Evolution in the Mediterranean; Oxford University Press Inc.: New York, NY, USA, 2005.

16. Whittaker, R.J.; Fernández-Palacios, J.M.; Matthews, T.J.; Borregaard, M.K.; Triantis, K.A. Island biogeography: Taking the long view of nature's laboratories. Science 2017, 357, 876-885. [CrossRef] [PubMed]

17. Snogerup, S. The Mediterranean Islands. In Plant conservation in the Mediterranean Area; Gomez Campo, C., Ed.; Springer: Dordrecht, The Netherlands, 1985; Volume 7, pp. 159-173.

18. Strid, A.; Tan, K. (Eds.) Flora Hellenica; University of Copenhagen, Koeltz Scientific Books: Koenigstein, Germany, 1997; 547p.

19. Blondel, J.; Aronson, J. Biology and Wildlife of the Mediterranean Region; Oxford University Press: Oxford, UK, 1999.

20. Clavel, J.; Julliard, R.; Devictor, V. Worldwide decline of specialist species: Toward a global functional homogenization? Front. Ecol. Environ. 2011, 9, 222-228. [CrossRef]

21. Lavergne, S.; Thompson, J.D.; Garnier, E.; Debussche, M. The biology and ecology of narrow endemic and widespread plants: A comparative study of trait variation in 20 congeneric pairs. Oikos 2004, 107, 505-518. [CrossRef]

22. Imbert, E.; Youssef, S.; Carbonell, D.; Baumel, A. Do endemic species always have a low competitive ability? A test for two Mediterranean plant species under controlled conditions. J. Plant Ecol. 2012, 5, 305-312. [CrossRef]

23. Gankin, R.; Major, J. Arctostaphylos myrtifolia, its biology and relationship to the problem of endemism. Ecology 1964, 45, 792-808. [CrossRef]

24. Panitsa, M.; Kontopanou, A. Diversity of chasmophytes in the vascular flora of Greece: Floristic analysis and phytogeographical patterns. Bot. Serbica 2017, 41, 199-211.

25. Kypriotakis, Z.; Tzanoudakis, D. Contribution to the study of the Greek insular flora: The chasmophytic flora of Crete. Bocconea 2001, 13, 495-503.

26. Cattaneo, C.; Grano, M. Contribution to the knowledge of vascular flora on Astypalea Island (Dodecanese, Greece). Phytol. Balc. 2016, 22, 405-417.

27. Médail, F.; Verlaque, R. Ecological characteristics and rarity of endemic plants from southeast France and Corsica: Implications for biodiversity conservation. Biol. Conserv. 1997, 80, 269-271. [CrossRef]

28. Runemark, H. The phytogeography of the Central Aegean. Opera Bot. 1971, 30, 20-28.

29. Escudero, A. Community patterns on exposed cliffs in a Mediterranean calcareous mountain. Vegetatio 1996, 125, 99-110. [CrossRef]

30. Aronne, G.; Arena, C.; De Micco, V.; Giovanetti, M.; Buonanno, M. Full light and soil drought constrain plant growth in Mediterranean cliffs: The case of Primula palinuri Petagna. Plant Biosyst. 2018, 152, 863-872. [CrossRef] 
31. Fois, M.; Cuena-Lombraña, A.; Fenu, G.; Bacchetta, G. Using species distribution models at local scale to guide the search of poorly known species: Review, methodological issues and future directions. Ecol. Model. 2018, 385, 124-132. [CrossRef]

32. Horvat, I.; Glavač, V.; Ellenberg, H. Vegetation Südosteuropas; G. Fischer: Stuttgart, Germany, 1974; 768p.

33. Zaffran, J. Contributions à la Flore et à la Végétation de la Crète; de l'Université de Provence: Marseille, Germany, 1990; p. 615.

34. Dimopoulos, P.; Sykora, K.V.; Mucina, L.; Georgiadis, T. The high-rank syntaxa of the rock-cliff and scree vegetation of the mainland Greece and Crete. Folia Geobot Phytotax 1997, 32, 313-334. [CrossRef]

35. Bergmeier, E. The vegetation of the high mountains of Crete-A revision and multivariate analysis. Phytocoenologia 2002, 32, 205-249. [CrossRef]

36. Bergmeier, E.; Dimopoulos, P.; Mucina, L. Validation of some alliances of the Aegean chasmophytic vegetation of the Asplenietea trichomanis. Lazaroa 2011, 32, 183-186.

37. Trigas, P.; Panitsa, M.; Tsiftsis, S. Elevational Gradient of Vascular Plant Species Richness and Endemism in Crete-Effect of Post-Isolation Mountain Uplift on a Continental Island System. PLoS ONE 2013, 8, e59425. [CrossRef] [PubMed]

38. McCain, C.M.; Grytnes, J.A. Elevational gradients in species richness. In Encyclopedia of Life Sciences (ELS); John Wiley \& Sons, Ltd.: Chichester, UK, 2010; pp. 1-10.

39. Steinbauer, M.J.; Field, R.; Grytnes, J.A.; Trigas, P.; Ah-Peng, C.; Attorre, F.; Birks, H.J.B.; Borges, P.A.; Cardoso, P.; Chou, C.H.; et al. Topography-driven isolation, speciation and a global increase of endemism with elevation. Glob. Ecol. Biogeogr. 2016, 25, 1097-1107. [CrossRef]

40. Steinbauer, M.J.; Irl, S.D.; Beierkuhnlein, C. Elevation-driven ecological isolation promotes diversification on Mediterranean islands. Acta Oecol. 2013, 47, 52-56. [CrossRef]

41. Nikolić, T.; Antonić, O.; Alegro, A.L.; Dobrović, I.; Bogdanović, S.; Liber, Z.; Rešetnik, I. Plant species diversity of Adriatic islands: An introductory survey. Plant Biosyst. 2008, 142, 435-445. [CrossRef]

42. Fois, M.; Fenu, G.; Cañadas, E.M.; Bacchetta, G. Disentangling the influence of environmental and anthropogenic factors on the distribution of endemic vascular plants in Sardinia. PLoS ONE 2017, 12, e0182539. [CrossRef]

43. Valli, A.T.; Kougioumoutzis, K.; Iliadou, E.; Panitsa, M.; Trigas, P. Determinants of alpha and beta vascular plant diversity in Mediterranean island systems: The Ionian islands, Greece. Nord. J. Bot. 2019, 37, e02156. [CrossRef]

44. Cellinese, N.; Smith, S.A.; Edwards, E.J.; Kim, S.T.; Haberle, R.C.; Avramakis, M.; Donoghue, M.J. Historical biogeography of the endemic Campanulaceae of Crete. J. Biogeogr. 2009, 36, 1253-1269. [CrossRef]

45. Bilz, M.; Kell, S.P.; Maxted, N.; Lansdown, R.V. European Red List of Vascular Plants; Publications Office of the European Union: Luxembourg, 2011.

46. Phitos, D.; Strid, A.; Snogerup, S.; Greuter, W. (Eds.) The Red Data Book of Rare and Threatened Plants of Greece; Worldwide Fund for Nature: Athens, Greece, 1995.

47. Phitos, D.; Konstantinidis, T.; Kamari, G. (Eds.) The Red Data Book of Rare and Threatened Plants of Greece (A-D); Hellenic Botanical Society: Patras, Greece, 2009.

48. Phitos, D.; Konstantinidis, T.; Kamari, G. (Eds.) The Red Data Book of Rare and Threatened Plants of Greece (E-Z); Hellenic Botanical Society: Patras, Greece, 2009.

49. Dimopoulos, P.; Raus, T.; Bergmeier, E.; Constantinidis, T.; Iatrou, G.; Kokkini, S.; Strid, A.; Tzanoudakis, D. Vascular Plants of Greece. An Annotated Checklist; Englera, 31; Botanischer Garten und Botanisches Museum Berlin-Dahlem: Berlin, Germany, 2013.

50. Oksanen, J.; Kindt, R.; Legendre, P.; O’Hara, B.; Stevens, M.H.H.; Oksanen, M.J.; Suggests, M.A.S.S. The vegan package. Community Ecol. Package 2007, 10, 631-637.

51. Latombe, G.; Hui, C.; McGeoch, M.A. Multi-site generalised dissimilarity modelling: Using zeta diversity to differentiate drivers of turnover in rare and widespread species. Methods Ecol. Evol. 2017, 8, 431-442. [CrossRef]

52. Hui, C.; McGeoch, M.A. Zeta diversity as a concept and metric that unifies incidence-based biodiversity patterns. Am. Nat. 2014, 184, 684-694. [CrossRef] [PubMed]

53. Latombe, G.; McGeoch, M.A.; Nipperess, D.; Hui, C. Zetadiv: Functions to Compute Compositional Turnover Using Zeta Diversity. R Package Version 1.0. 2017. Available online: https://cran.r-project.org/package= zetadiv (accessed on 17 May 2017). 
54. Directive, H. Council Directive 92/43/ EEC of 21 May 1992 on the conservation of natural habitats and of wild fauna and flora. Off. J. Eur. Union 1992, 206, 7-50.

55. IUCN The IUCN Red List of Threatened Species. Version 2019-3. 2019. Available online: http://www. iucnredlist.org (accessed on 10 December 2019).

56. Pasta, S.; Perez-Graber, A.; Fazan, L.; de Montmollin, B. (Eds.) The Top 50 Mediterranean Island Plants Update 2017; E-Book and Online; IUCN/SSC/Mediterranean Plant Specialist Group: Neuchâtel, Switzerland, 2017; p. 144. Available online: http://top50.iucn-mpsg.org (accessed on 31 December 2017).

57. Steinbauer, M.J.; Otto, R.; Naranjo-Cigala, A.; Beierkuhnlein, C.; Fernández-Palacios, J.M. Increase of island endemism with altitude-Speciation processes on oceanic islands. Ecography 2012, 35, 23-32. [CrossRef]

58. Vogiatzakis, I. Mediterranean Mountain Environments; John Wiley \& Sons: Chichester, UK, 2012.

59. Zhao, Y.J.; Gong, X. Diversity and conservation of plant species in dry valleys, southwest 498 China. Biodivers. Conserv. 2015, 24, 2611-2623. [CrossRef]

60. Cutts, V.; Katal, N.; Löwer, C.; Algar, A.C.; Steinbauer, M.J.; Irl, S.D.; Beierkuhnlein, C.; Field, R. The effect of small-scale topography on patterns of endemism within islands. Front. Biogeogr. 2019, 11, e43737. [CrossRef]

61. Dimopoulos, P.; Raus, T.; Bergmeier, E.; Constantinidis, T.; Iatrou, G.; Kokkini, S.; Strid, A.; Tzanoudakis, D. Vascular Plants of Greece. An Annotated Checklist. Willdenowia (Supplement) 2016, 46, 301-347. [CrossRef]

62. Jeanmonod, D.; Naciri, Y.; Schlüssel, A.; Gamisans, J. Floristic analyses of the Corsican flora: Biogeographical origin and endemism. Candollea 2015, 70, 21-42. [CrossRef]

63. Bacchetta, G.; Casti, M.; Mossa, L. New ecological and distributive data on the rupestrian flora of Sardinia. J. Bot. Soc. Bot. Fr. 2007, 38, 73-83.

64. Beard, J.S.; Chapman, A.R.; Gioia, P. Species richness and endemism in the western Australian flora. J. Biogeogr. 2000, 27, 1257-1268. [CrossRef]

65. Wagenitz, G. Centaurea in South-West Asia: Patterns of distribution and diversity. Proc. R. Soc. Edinb. 1986, 89, 11-21. [CrossRef]

66. Hellwig, F.H. Centaureinae (Asteraceae) in the Mediterranean history of ecogeographical radiation. Plant Syst. Evol. 2004, 246, 137-162. [CrossRef]

67. Trigas, P.; Iatrou, G.; Karetsos, G. Species diversity, endemism and conservation of the family Caryophyllaceae in Greece. Biodivers. Conserv. 2007, 16, 357-376. [CrossRef]

68. Heywood, V.H.; Brummitt, R.K.; Culham, A.; Seberg, O. Flowering Plant Families of the World; Kew Royal Botanic Gardens: Kew, UK, 2007.

69. Eddie, W.M.M.; Shulkina, T.; Gaskin, J.; Haberle, R.C.; Jansen, R.K. Phylogeny of Campanulaceae S. Str. Inferred from Its Sequences of Nuclear Ribosomal DNA. Ann. Mo. Bot. Gard. 2003, 90, 554-575. [CrossRef]

70. Georghiou, K.; Delipetrou, P. Patterns and traits of the endemic plants of Greece. Bot. J. Linn. Soc. 2010, 162, 130-422. [CrossRef]

71. Carlsson, B.A.; Karlsson, P.S.; Svensson, B.M. Alpine and subalpine vegetation. Acta Phytogeogr. Suec. 1999, 84, 75-90.

72. Körner, C. Alpine plant life. In Functional Plant Ecology of High Mountain Ecosystems; Springer Science \& Business Media: Berlin/Heidelberg, Germany, 2003.

73. Lazarina, M.; Charalampopoulos, A.; Psaralexi, M.; Krigas, N.; Michailidou, D.E.; Kallimanis, A.S.; Sgardelis, S.P. Diversity Patterns of Different Life Forms of Plants along an Elevational Gradient in Crete, Greece. Diversity 2019, 11, 200. [CrossRef]

74. Vogiatzakis, I.; Griffiths, G.H.; Mannion, A.M. Environmental factors and vegetation composition, Lefka Ori massif, Crete, S. Aegean. Glob. Ecol. Biogeogr. 2003, 12, 131-146. [CrossRef]

75. Kougioumoutzis, K.; Simaiakis, S.M.; Tiniakou, A. Network biogeographical analysis of the central Aegean archipelago. J. Biogeogr. 2014, 41, 1848-1858. [CrossRef]

76. Kallimanis, A.S.; Panitsa, M.; Bergmeier, E.; Dimopoulos, P. Examining the relationship between total species richness and single island palaeo- and neo-endemics. Acta Oecol. 2011, 37, 65-70. [CrossRef]

77. Thomas, G.H.; Orme, C.D.L.; Davies, R.G.; Olson, V.A.; Bennett, P.M.; Gaston, K.J.; Owens, I.P.F.; Blackburn, T.M. Regional variation in the historical components of global avian 486 species richness. Glob. Ecol. Biogeogr. 2008, 17, 340-351. [CrossRef]

78. Verboom, G.A.; Bergh, N.G.; Haiden, S.A.; Hoffmann, V.; Britton, M.N. Topography as a 488 driver of diversification in the Cape Floristic Region of South Africa. New Phytol. 2015, 207, 368-376. [CrossRef] [PubMed] 
79. Xing, Y.; Ree, R.H. Uplift-driven diversification in the Hengduan Mountains, a temperate biodiversity hotspot. Proc. Natl. Acad. Sci. USA 2017, 114, 3444-3496. [CrossRef]

80. Gentili, R.; Bacchetta, G.; Fenu, G.; Cogoni, D.; Abeli, T.; Rossi, G.; Salvatore, M.C.; Baroni, C.; Citterio, S. From cold to warm stage refugia for boreo-alpine plants in southern European and Mediterranean mountains: The last chance to survive or an opportunity for speciation? Biodiversity 2015, 16, 247-261. [CrossRef]

81. De Castro Godinho, M.B.; Da Silva, F.R. The influence of riverine barriers, climate, and 423 topography on the biogeographic regionalization of Amazonian anurans. Sci. Rep. 2018, 8, 3427. [CrossRef]

82. Harrison, S.; Noss, R. Endemism hotspots are linked to stable climatic refugia. Ann. Bot. 2017, 119, $207-214$. [CrossRef]

83. Rechinger, K.H. Der Endemismus in der griechischen Flora. Rev. Roumaine Biol. Ser. Bot. 1965, 10, $135-138$.

84. Panitsa, M.; Trigas, P.; Iatrou, G.; Sfenthourakis, S. Factors affecting plant species richness and endemism on land-bridge islands-An example from the East Aegean archipelago. Acta Oecol. 2010, 36, 431-437. [CrossRef]

85. Lazarina, M.; Kallimanis, S.; Dimopoulos, P.; Psaralexi, M.; Michailidou, D.E.; Sgardelis, S. Patterns and drivers of species richness and turnover of neo-endemic and palaeo-endemic vascular plants in a Mediterranean hotspot: The case of Crete, Greece. J. Biol. Res. Thessalon. 2019, 26, 12-25. [CrossRef]

86. Tomaselli, M.; Foggi, B.; Carbognani, M.; Gennai, M.; Petraglia, A. The rock-face vegetation in the northern Apennines and neighbouring mountain areas, from the coastline to the highest summits. Phytocoenologia 2019, 49, 7-70. [CrossRef]

87. Lenoir, J.; Svenning, J.C. Climate-related range shifts-A global multidimensional synthesis and new research directions. Ecography 2015, 38, 15-28. [CrossRef]

88. Steinbauer, M.J.; Grytnes, J.; Jurasinski, G.; Kulonen, A.; Lenoir, J.; Pauli, H.; Rixen, C.; Winkler, M.; Bardy-Durchhalter, M.; Barni, E.; et al. Accelerated increase in plant species richness on mountain summits is linked to warming. Nature 2018, 556, 231-234. [CrossRef] [PubMed]

89. Alexander, J.M.; Diez, J.M.; Levine, J.M. Novel competitors shape species' responses to climate change. Nature 2015, 525, 515-518. [CrossRef]

90. Borges, P.A.V.; Cardoso, P.; Kreft, H.; Whittaker, R.J.; Fattorini, S.; Emerson, B.C.; Gil, A.; Gillespie, R.G.; Matthews, T.J.; Santos, A.M.; et al. Global Island Monitoring Scheme (GIMS): A proposal for the long-term coordinated survey and monitoring of native island forest biota. Biodivers. Conserv. 2018, 27, 2567. [CrossRef]

91. Grabherr, G.; Gottfried, M.; Pauli, H. GLORIA: A global observation research initiative in alpine environments. Mt. Res. Dev. 2000, 20, 190-191. [CrossRef]

92. Alexander, J.M.; Kueffer, C.; Daehler, C.C.; Edwards, P.J.; Pauchard, A.; Seipel, T. MIREM consortium, Assembly of non-native floras along elevational gradients explained by directional ecological filtering. Proc. Natl. Acad. Sci. USA 2011, 108, 656-661. [CrossRef]

93. Fernandez-Calzado, R.; Ghosn, D.; Gottfried, M.; Kazakis, G.; Molero Mesa, J.; Pauli, H.; Merzouki, A. Patterns of endemism along an elevation gradient in Sierra Nevada (Spain) and Lefka Ori (Crete, Greece). Pirineos. Revista de Ecología de Montaña 2003, 168, 7-24. [CrossRef]

94. Porro, F.; Tomaselli, M.; Abeli, T.; Gandini, M.; Gualmini, M.; Orsenigo, S.; Petraglia, A.; Rossi, G.; Carbognani, M. Could plant diversity metrics explain climate-driven vegetation changes on mountain summits of the GLORIA network? Biodivers. Conserv. 2019, 28, 3575-3596. [CrossRef]

95. European Commission. Doc. Hab.12-04/06; European Commission: Brussels, Belgium, 2012. Available online: https:/ec.europa.eu/environment/nature/natura2000/management/docs/commission_note/commission_ note2_EN.pdf (accessed on 17 January 2019).

96. Crain, B.; Cuervo, S.; Ana, M.; White, J.; Steinberg, S. Conservation ecology of rare plants within complex local habitat networks. Oryx 2015, 49, 696-703. [CrossRef]

(C) 2020 by the authors. Licensee MDPI, Basel, Switzerland. This article is an open access article distributed under the terms and conditions of the Creative Commons Attribution (CC BY) license (http://creativecommons.org/licenses/by/4.0/). 